\title{
PERFORMANCE AND SOME BLOOD SERUM CONSTIT- UENTS OF GROWING BUFFALO CALVES FED RATIONS CONTAINING CORN SILAGE
}

\author{
Nassif, M.N. \\ Animal Medicine Department, Faculty of Veterinary \\ Medicine, Kafr El-Sheikh, Tanta University.
}

\begin{abstract}
Twenty growing male buffalo calves with averagebodyweight of $120 \mathrm{kgs}$ and 6-9 month of age were used in this investigation and divided into two equal groups each of ten animals. The first group was fed corn silage alone for three months, while the second control group received a control ration. The first group showed clinical manifestions of $\mathrm{Cu}$, $\mathrm{Zn}$, Se and vitamin A deficiencies with prevalence particular signs of unthriftness, weight loss, rough hair coat, alopecia in some parts of the body and hypopigmentation, also diarrhoea, bilateral ocular discharge and coughing be noticed in some animals may. Chemical analysis of the diet revealed that, corn silage alone is not a balanced diet for growing calves. Blood serum biochemical analysis of the diseased calves reflected these dietary deficiencies, as it revealed a significant reduction of the previous trace elements together with significant depletion in serum calcium,vitamin A and total proteins in comparison with the control animals.Haematological picture of the diseased calves revealed hypochromic microcytic anaemia, which is indicative for copper deficiency.Diseased calves responded successfully to supplem-entation of concentrate feed mixture and parentral injection of copper methionate and vitamin A together with dietary mineral supplementation as clinical signs disappeared and all examined blood parameters showed significant improvement towards the normal levels.
\end{abstract}

\section{INTRODUCTION}

Corn silage alone is not a balanced diet,therefore,consideration must be given to adding essential nutrients(Tilden and Michael,1995).Feeding 
silage alone does not support optimum growth rates of growing calves. Therefore, varying levels of grains may be fed with silage to provide appropriate energy for desired rates of gain and production. Minerals, such as calcium, phosphorus, salt, cobalt and possibly zinc should be provided in a supplement as a portion of the diet, or by feeding in a box on a free-choice basis. Recent research indicates that urea and mineral additions to corn silage at ensiling improve the energy value of the silage as feed for beef cattle from 5-10\%, in addition to increase in the rate of gain and feed efficiency (Pond, et al. 1995). In earlier, research, (Perry et al. 1976) found that, calves fed a diet of corn silage showed low blood selenium and one calf had died of possible white muscle disease. Also, (McDonaled et al.,1966) concluded that, corn silage may have lost practically all of its carotene after it was harvested and stored under anaerobic conditions for several months where oxygen and heat was available. Likewise, (Tilden and Michael, 1995) stated that, the carotenes are destroyed by exposure to oxygen or heat during ensiled crops. Smith (2002) and Gunter et al. (2003) reported that, slowed growth and lessthan normal weight gains usually occur at the same time, however, they occasionally occur separately accompanied trace elements and vitamins deficiencies.So, this work aimed to study the effect of feeding corn silage with or without concentrate feed mixture on general health condition,performance and some blood serum constituents of growing buffalo calves.

\section{MATERIALS AND METHODS}

\section{Animals:}

The current work was carried out at private farm of animal production, Belqas,Dakahlia province. Twenty growing male buffalo calves with average body weight of $120 \mathrm{kgs}$ and 6-9 months of age were included in the present investigation. They were divided into two equal groups, diseased group (G1) has prevalence of particular signs of unthriftness, slow growth rate and alopecia,in addition to diarrhea,bilateral lacrimation and coughing 
in some animals.Another apparently clinically healthy group was used,as a control group (G2).

\section{Diets:}

Growing buffalo calves of the first group (G1) were fed corn silage alone adlibtium for three months (pre-treatment). During post treatment, calves fed ration composed of $50 \%$ corn silage and $50 \%$ concentrate mixture(CFM)for ten weeks, while the second group received 50\%CFM,25\% rice straw and $25 \%$ berseem hay (control ration) to cover the requirements of growing calves according to (NRC, 1996) as shown in Table 1. CFM consists of yellow corn grain, soyabean meal, wheat bran, urea, at 63, 16, $20,1, \%$, respectively.

Concentrate feed mixture was given twice daily at 8.00 a.m and 5.00 p.m, while corn silage was given at 9.00 a.m and 6.00 p.m. Fresh water was available for calves all the day round.

\section{Clinical examination:}

History and complete physical examination of all calves were carried out according to Kelly (1990).

\section{Blood samples:}

Two blood samples were collected from each investigated calf before and ten weeks after treatment. The first heparinized blood sample was analyzed for haematological picture using electronic cell counter(Msg,France), while the second blood sample was used to obtain clear, non haemolysed serum for colorimetric determination of inorganic phosphorus (Kilching and Freiburg, 1951), vitamin A (Nobert, 1986), total proteins (Weichsclbaum, 1946), on the other hand atomic absorption spectrophotometer procedure (Perkin Elmer, 2380) was used for determination of $\mathrm{Ca}, \mathrm{Cu}, \mathrm{Zn}$, $\mathrm{Mn}, \mathrm{Se}$ and Fe.

\section{Diet analysis:}


Samples of diet offered to each group were chemically analyzed for minerals and trace elements according to $\boldsymbol{A O A C ( 1 9 9 0 )}$ using atomic absorption spectrophotometer procedure (Perkin Elmer 2380).

\section{Parasitological examination:}

Skin scraping as well as fecal samples was collected from diseased calves for parasitological examination according to Kelly(1990)to ensure that calves are free from any parasitic skin disease or internal parasites as specific antiparastic drugs were used in this farm.

\section{Treatment of diseased calves:}

Diseased calves were injected intramuscular with 1 million I.U of vitamin A /calf (Radostits et al.,2000) together with intramuscular injection of copper in the form of copper methionate(Coppa Comp.,Bimedia. Broomhill Rd, Tallaght, Dublin 24) (20mg Cu/ml)at dose rate of $3 \mathrm{ml} /$ head/week for three successive weeks (Randhawa et al.,1994), in addition to continuous supplementation of mineral salts.

\section{Statistical analysis:}

The obtained data were statistically analyzed using general linear model procedure adapted by SPSS (1995).

\section{RESULTS AND DISCUSSION}

In agreement with a previous report $(N R C, 2002)$, corn silage feed is deficient in calcium,crude protein,sodium,copper,zinc and selenium., Also Pond et al.(1995) previously concluded that,corn silage as a feed for cattle is deficient in protein,calcium and phosphorus(dry matter basis )8.1, 0.27 and $0.20 \%$;respectively, while the requirements for growing calves (1.651 bs daily gain) are $11.1,0.31$ and $0.25 \%$; respectively. So urea, dicalcium phosphate and mineral mixture are often added to corn silage at silo filling time to correct protein and mineral deficiencies. Moreover, Adam (1988) mentioned that, cattle consuming ration rich in corn silage or oat silage 
have been found to be deplete normal store of vitamin $A$ in the liver even thought these feeds contained medium to high levels of $B$-carotene.He also added that the requirement of heifers or steers wintered in corn silage is 15,000 i.u of vitamin A per head daily.

Copper, zinc, selenium and vitamin A deficiencies are among the major problems in calves and are intimately concerned with optimal health and performancePond et al.,(1995);Machen et al.,(1996)and Smith, (2002). Diseased calves fed corn silage alone revealed unthriftness, poor weight gain,rough easily sheding hair coat from various parts of the body (Fig .1), anaemia, anorexia, frequent diarrhoea, lacrimation,scaly skin, and achromotrichia,additionally some calves were suffering from coughing.It is clearly seen that,these findings coincided with that of copper,zinc,sele-nium and vitamin A deficiencies and this came in agreement with those previously recorded by Nasser et al., (2000); Cerone et al.,(2000);Smith, (2002); Mullis et al., (2003) and Gunter et al., (2003). Enjalbert et al., (1997) indicated that,mortality and morbidity rates in cattle herd were not significantly increased by feeding corn silage, but weight loss and decre-ased gain accompanied such diet may be attributed to nitrogen deficiency and lack of mineral complementation increased the risk of diarrhoea.

Hypopigmentation may be attributed to copper containing enzyme, tyrosinase ( polyphenyloxidase) which is needed to convert L- tyrosine to melanin and with copper deficiency this conversion is slow and hair is lighter in color than normal(Machen et al,(1996)and Smith,(2002). Diarrhoea and coughing of deficient buffalo calves may be attributed to reduced immunity. Jones and Suttle, (1981),Xin et al.(1991) and Cerone et al. (2000) indicated that,copper and zinc deficiencies alter the activity of several enzymes (copper and zinc superoxide dismutase and cytochrome C oxidase) in peripheral blood lymphocytes, neutrophils and monocytesderived macrophages which mediate antioxidant defense and ATP formation and these effects may impair the cell immune functionality,affecting $\overline{\mathrm{Kafr}}$ El-Sheikh Vet. Med. J. Vol. 2 No. 2 (2004) 
the bactericidal capacity and making the animal more susceptible to infection. Additionally, Stable et al. (1989) and Bailey et al. (2001) found that, selenium deficiency decreased the immunity of calves through decreasing IgM formation following stress. On the other hand, Arrayet et al. (2002) contributed immunosuppression, poor growth and death in Holstein calves to zinc deficiency.

Deficiency of single trace element rarely occur in the field, as deficiency is complicated by close inter-relation of many trace elements and various metabolic processes as the imbalance in the intake or metabolism of one element may change the requirement of the others Hidiroglou, (1979). The present study revealed that,blood serum biochemical analysis of investigated unthrifty buffalo calves showed significant reduction in calcium, total proteins and trace elements especially copper, zinc, and selenium in comparison with healthy ones (Table 4) and this agreed with previous reports of Nasr, (1993) and Nasser et al. (2000). Also, unthrifty calves proved significant decrease in serum vitamin A (Table 4). Tilden and Michael, (1995) contributed vitamin A deficiency to its destruction by heat,humidity,prolonged bad storage and other adverse environmental conditions. On the other hand, Yavuz et al. (1991) attributed vitamin A deficiency in beef cattle feeding silage to the reduction of $\beta$-carotene retention in the rumen as a result of high nitrite in the silage leading to inefficient conversion of carotene to vitamin A.

The obtained haematological values as recorded in table (5) are indicative for the presence of copper deficiency in growing buffalo calves feeding corn silage alone in comparison with healthy control ones. Diseased calves revealed significant $(\mathrm{P}<0.01)$ decrease in both haemoglobin and erythrocytic count indicating hypochromic microcytic anaemia. These results agreed with previous study of Nasser, et al.(2000) and Radostits et al. (2000). Xin et al. (1991) and Smith, (2002) reported that, copper plays an important role in the transport of iron from the gut to marrow 
and incorporation of iron into the haeme moiety,so the anaemia produced by copper deficiency is closely resembles iron deficiency in that,it is usually a microcytic hypochromic anaemia. On the other hand, insignificant changes were observed in total leukocytic count in deficient claves, but differential leukocytic count showed significant variations in comparison with control group (Table 5). These results coincided with Cerone et al. (1998) and Cerone et al. (2000) who proved that, in copper deficient animals, total leukocytic numbers were not affected, but differential count showed a marked increase in monocytes subpopulation and significant decrease in lymphocytes and neutrophils. They also concluded that, these changes reduce the animal's immune competence may contributed to greater incidence of infectious diseases in copper deficient cattle.

All recorded clinical signs disappeared after supplementation of CFM to the diet of calves together with intramuscular injection of copper methionate and vitamin A and dietary mineral mixture supplementation. In addition to all blood values showed significant improvement towards the normal levels (Tables $4 \& 5$ ). These results were similar with those reported by Nasr, (1993), Pechin et al. (1999) Gierus et al. (2002) and Gunter et al. (2003).

Finally, it could be concluded that,corn silage alone is not a balanced diet and feeding it alone does not support optimum growth rates of growing buffalo calves, therefore, consideration must be given to fed concentrate feed mixture with silage to provide appropriate energy for desired rate of gain and production. Additionally mineral mixture and vitamin A supplements should be included in corn silage based diet.

Table (1): Formulation of the rations fed to growing buffalo calves before and after treatment.

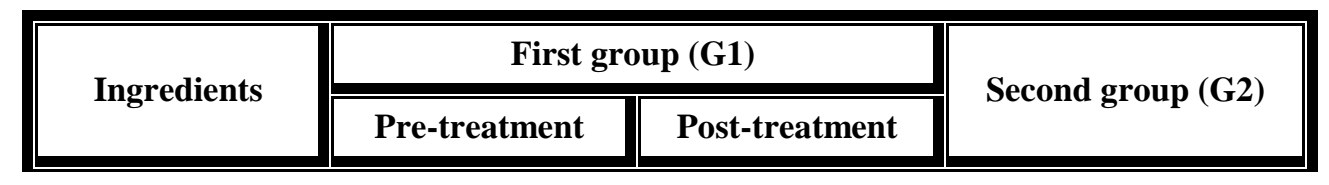

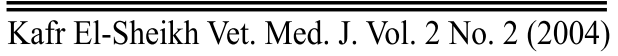




\begin{tabular}{|l||c||c||c|}
\hline \hline Corn silage \% & 100 & 50 & 0.00 \\
CFM \% & 0.00 & 50 & 50 \\
Rice straw \% & 0.00 & 00 & 25 \\
Berseem hay \% & 0.00 & 00 & 25 \\
\hline
\end{tabular}

Table (2): Chemical composition(on dry matter basis) of feed ingredients fed to growing buffalo calves.

\begin{tabular}{||l|c|c|c|c|c|c||c|}
\hline \multirow{2}{*}{\multicolumn{1}{|c||}{ Ingredients }} & \multirow{2}{*}{ DM\% } & \multicolumn{6}{c|}{ Composition of DM \% } \\
\cline { 3 - 8 } & & OM & CP & EE & CF & NFE & Ash \\
\hline \hline Corn silage & 38.56 & 92.44 & 6.46 & 2.30 & 29.77 & 53.91 & 7.56 \\
Wheat bran & 89.10 & 93.50 & 15.50 & 4.40 & 11.00 & 62.60 & 6.50 \\
Yellow corn & 88.00 & 98.50 & 9.50 & 4.10 & 2.50 & 82.40 & 1.50 \\
Soyabean meal & 88.85 & 92.80 & 48.52 & 1.80 & 6.23 & 36.25 & 7.20 \\
Urea & 100 & & 280 & & & & \\
Rice straw & 92.34 & 82.40 & 3.40 & 1.75 & 30.81 & 46.44 & 17.60 \\
Berseem hay & 90.68 & 87.50 & 14.20 & 2.50 & 24.85 & 45.95 & 12.50 \\
Experimental rations (Calculated) & & & & & & \\
After treat. (G1) & 100 & 94.52 & 13.05 & 3.03 & 17.27 & 61.17 & 5.48 \\
Control ration (G2) & 100 & 90.77 & 14.22 & 2.94 & 16.30 & 57.31 & 9.23 \\
\hline
\end{tabular}

Table (3): Minerals concentration(on DM basis)of ingredients fed to growing buffalo calves.

\begin{tabular}{|c|c|c|c|c|c|c|c|c|c|c|c|}
\hline \multirow{2}{*}{ Ingredients } & \multicolumn{6}{|c|}{ Macro elements \% } & \multicolumn{5}{|c|}{ Micro elements, ppm } \\
\hline & $\mathbf{C a}$ & $\mathbf{P}$ & Mg & $\mathbf{K}$ & $\mathbf{N a}$ & $\mathbf{S}$ & $\mathbf{C u}$ & $\mathbf{F e}$ & Mn & Se & Zn \\
\hline Corn silage & 0.15 & 0.13 & 0.13 & 1.25 & 0.02 & 0.09 & 3 & 120 & 20 & 0.02 & 15 \\
\hline Wheat bran & 0.15 & 1.10 & 0.45 & 1.85 & 0.03 & 0.25 & 12 & 170 & 110 & 0.38 & 75 \\
\hline Yellow corn & 0.02 & 0.22 & 0.13 & 0.65 & 0.01 & 0.13 & 2 & 45 & 8 & 0.04 & 20 \\
\hline Soyabean meal & 0.55 & 0.75 & 0.38 & 2.65 & 0.05 & 0.56 & 18 & 210 & 27 & 0.13 & 60 \\
\hline Rice straw & 0.60 & 0.11 & 0.22 & 2.03 & 0.28 & 0.13 & 6 & 120 & 40 & 0.01 & 25 \\
\hline Berseem hay & 1.40 & 0.30 & 0.30 & 2.90 & 0.10 & 0.25 & 10 & 375 & 50 & 0.20 & 45 \\
\hline
\end{tabular}

Kafr El-Sheikh Vet. Med. J. Vol. 2 No. 2 (2004) 
Performance And Some Blood Serum Constituents Of Growing ...

Nassif, M.N.

\begin{tabular}{|l||l|l|l|l|l|l|l|l|l|l|l||l|l||}
\hline \hline After treat. & 0.14 & 0.30 & 0.18 & 1.23 & 0.02 & 0.16 & 5 & 108 & 26 & 0.07 & 26 \\
\cline { 2 - 12 } \cline { 3 - 9 } & 0.55 & 0.31 & 0.23 & 1.73 & 0.10 & 0.19 & 7 & 163 & 37 & 0.11 & 34 \\
\hline Control ration
\end{tabular}

*Experimental ration after treatment was supplemented with $\mathrm{CaCO}_{3}$ and $\mathrm{NaCl}$ to provide $0.4 \% \mathrm{Ca}$ and $0.1 \% \mathrm{Na}$ while salt premix was $\mathrm{CuSO}_{4} .5 \mathrm{H}_{2} \mathrm{O}, \mathrm{MnSO}_{4} .4 \mathrm{H}_{2} \mathrm{O}, \mathrm{Na}_{2} \mathrm{SeSO}_{3}$, and $\mathrm{ZnSO}_{4} \cdot 7 \mathrm{H}_{2} \mathrm{O}$ to provide $5 \mathrm{Cu}, 14 \mathrm{Mn}, 0.23 \mathrm{Se}$, and $14 \mathrm{Zn} \mathrm{mg} / \mathrm{kg} \mathrm{DM}$, respectively.

Table (4): Blood serum biochemical parameters in healthy and diseased calves before and after treatment.

\begin{tabular}{|c|c|c|c|c|}
\hline \multirow{2}{*}{ Parameter } & \multirow{2}{*}{ Unit } & \multicolumn{2}{|c|}{ First group $($ G1 $) n=10$} & \multirow{2}{*}{$\begin{array}{c}\text { Second group } \\
(\text { G2) } n=10\end{array}$} \\
\hline & & $\begin{array}{l}\text { Before Treatment } \\
\qquad \mathbf{n}=\mathbf{1 0}\end{array}$ & $\begin{array}{c}\text { After Treatment } \\
\qquad \mathbf{n}=\mathbf{1 0}\end{array}$ & \\
\hline $\begin{array}{l}\text { Ca } \\
\text { Inorganic P } \\
\text { Cu } \\
\text { Mn } \\
\text { Se } \\
\text { Zn } \\
\text { Fe } \\
\text { Total Proteins } \\
\text { Vitamin A }\end{array}$ & $\begin{array}{l}\mathrm{mg} / \mathrm{dl} \\
\mathrm{mg} / \mathrm{dI} \\
\mu \mathrm{g} / \mathrm{dI} \\
\mu \mathrm{g} / \mathrm{dI} \\
\mu \mathrm{g} / \mathrm{dI} \\
\mu \mathrm{g} / \mathrm{dI} \\
\mu \mathrm{g} / \mathrm{dI} \\
\mathrm{g} / \mathrm{dI} \\
\mu \mathrm{g} / \mathrm{dI}\end{array}$ & $\begin{array}{c}9.03 \pm .26^{\mathrm{a}} \\
6.54 \pm .21 \\
70.00 \pm 3.85^{\mathrm{a}} \\
2.09 \pm .02^{\mathrm{a}} \\
.013 \pm .0008^{\mathrm{a}} \\
75.25 \pm 3.35^{\mathrm{a}} \\
136.88 \pm 2.51 \\
5.35 \pm .25^{\mathrm{a}} \\
18.50 \pm 1.35^{\mathrm{a}}\end{array}$ & $\begin{array}{c}9.86 \pm .28^{\mathrm{b}} \\
6.78 \pm .24 \\
90.25 \pm 3.91^{\mathrm{b}} \\
2.61 \pm .07^{\mathrm{b}} \\
.030 \pm .001^{\mathrm{b}} \\
90.25 \pm 2.07^{\mathrm{b}} \\
151.13 \pm 5.46 \\
6.81 \pm .32^{\mathrm{b}} \\
29.5 \pm .87^{\mathrm{b}}\end{array}$ & $\begin{array}{c}10.18 \pm .25^{\mathrm{b}} \\
7.14 \pm .22 \\
93.38 \pm 2.99^{\mathrm{b}} \\
2.60 \pm .08^{\mathrm{b}} \\
.035 \pm .001^{\mathrm{c}} \\
92.63 \pm 2.05^{\mathrm{b}} \\
148.75 \pm 6.08 \\
7.03 \pm .33^{\mathrm{b}} \\
34 \pm .93^{\mathrm{c}}\end{array}$ \\
\hline
\end{tabular}

Overall means within rows with different superscripts $(\mathrm{P}<0.05)$

Table (5): Haematological values in healthy and diseased calves before and after treatment.

\begin{tabular}{|c|c|c|c|c|}
\hline \multirow{2}{*}{ Parameter } & \multirow{2}{*}{ Unit } & \multicolumn{2}{|c|}{ First group (G1) } & \multirow{2}{*}{$\begin{array}{l}\text { Second group } \\
(\text { G2) } n=10\end{array}$} \\
\hline & & $\begin{array}{l}\text { Before Treatment } \\
\qquad=10\end{array}$ & $\begin{array}{l}\text { After Treatment } \\
\qquad \mathbf{n}=\mathbf{1 0}\end{array}$ & \\
\hline RBCs & $10^{6} / \mu \mathrm{L}$ & $8.19 \pm 0.30^{b}$ & $8.68 \pm 0.45^{b}$ & $12.1 \pm 0.35^{\mathrm{a}}$ \\
\hline $\mathrm{Hb}$ & $\mathrm{g} / \mathrm{dL}$ & $8.4 \pm 0.27^{\mathrm{b}}$ & $11.1 \pm 0.13^{\mathrm{a}}$ & $12.5 \pm 0.10^{\mathrm{a}}$ \\
\hline Platlets & $10^{3} / \mu \mathrm{L}$ & $125.0 \pm 10.1^{\mathrm{c}}$ & $197.2 \pm 9.5^{\mathrm{b}}$ & $280 \pm 20.3^{a}$ \\
\hline WBCs & $10^{3} / \mu \mathrm{L}$ & $7.32 \pm 0.13$ & $7.04 \pm 0.23$ & $7.5 \pm 0.7$ \\
\hline Lymphocytes & $\%$ & $46.2 \pm 3.2^{\mathrm{b}}$ & $56.1 \pm 2.2^{\mathrm{a}}$ & $55.8 \pm 3.2^{\mathrm{a}}$ \\
\hline Monocytes & $\%$ & $18.2 \pm 3.2^{\mathrm{a}}$ & $12.3 \pm 2.1^{\mathrm{c}}$ & $14.1 \pm 3.1^{\mathrm{b}}$ \\
\hline Granulocytes & $\%$ & $33.1 \pm 7.2^{\mathrm{a}}$ & $31.1 \pm 0.3^{\mathrm{b}}$ & $32.2 \pm 6.1^{\mathrm{a}}$ \\
\hline
\end{tabular}

$\overline{\text { Kafr El-Sheikh Vet. Med. J. Vol. } 2 \text { No. } 2 \text { (2004) }}$ 
Overall means within rows with different superscripts $(\mathrm{p}<0.05)$.

\section{ACKNOWLEDGEMENT}

My deep thanks to Prof.Dr./El-Sayed Abdel-Raouf.Prof. of Animal Nutrition and head of Animal production,Department,Fac. of Agriculture ,Kafr El-Shiekh for his great help in the diet analysis.

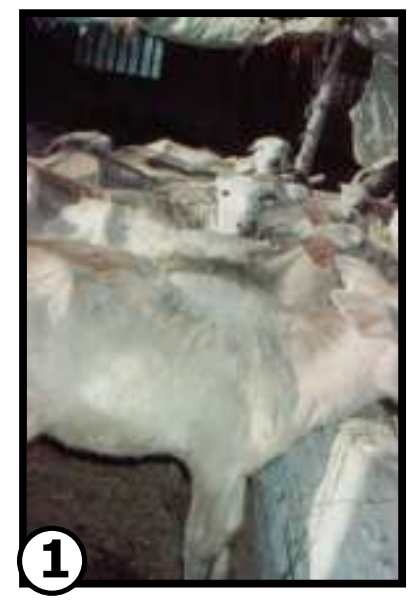

Fig. (1): Buffalo-calves showed unthriftness, weight loss, alopecia and hypopigmentation.

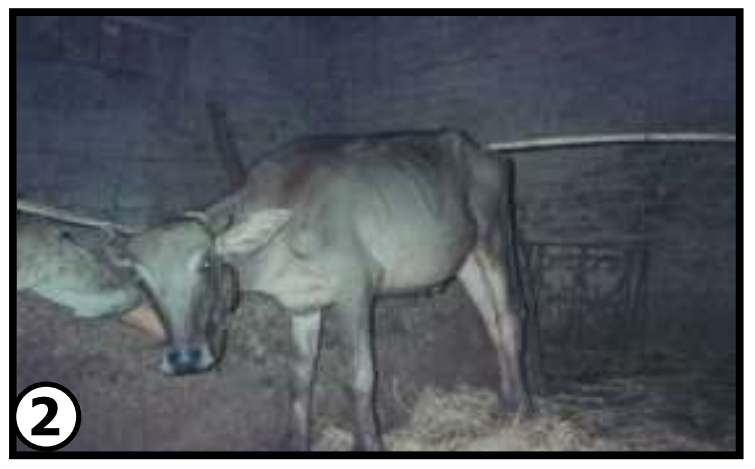

Fig. (2): Buffalo-calf 10 weeks after treatement.

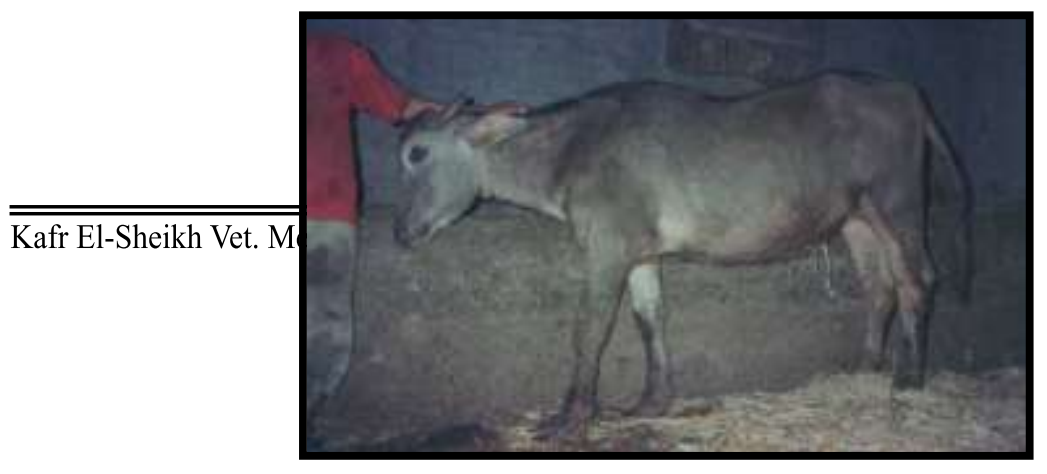




\section{(3)}

Fig. (3): Buffalo-calf of the same age (control group). 


\section{REFERENCES}

- Adam,J.(1988): Outbreak of aflatoxicosis in cattle with vitamin A defi-ciency,endometritis,laminitis in adult and diarrhoea in calves. Bulletin - Mensuel-de-la societe - Veterinaire- Pratiauede-France -72:2, 77-78.

- AOAC (1990): Association of Officiat Chemists, Official Methods of Analysis. $4^{\text {th }}$.Ed. (Ed. W. Horwitz Washington D.C ).

- Arrayet, J.L.; Oberbauer, A.M.; Famula, T.R.; Garnett, I.; Oltjen, J.W.; Imhoof, J.; Kehrli, M.E. and Graham, T.W. (2002): Growth of Holstein calves from birth to go days: The influence of dietary zinc and BLAD status. J.Anim. Sci. 80, 445-452.

- Bailey, J.D.; Ansotegui, R.P.; Paterdon, J.A.; Swenson, C.K. and Johnon, A.B. (2001): Effects of supplementing combination of inorg-anic and complexed copper on performance and liver mineral status of beef heifer consuming antagonists. J. Anim. Sci.,79(11), 2926-34.

- Cerone, S.I.; Sansinanea , A.S.; Streitnberger, S.A;Garcia, M.C.; Auza, N.J.(1998): The effect of copper deficiency on the peripheral blood cell of cattle.Veterinary Research Communications. 22 (1)47-57.

- Cerone, S.I.; Sansinanea, A.S.; Streitenberger, S.A.; Garcia, M.C. and Auza,N.J.(2000): Cytochrome $\mathrm{C}$ oxidase $\mathrm{Cu}, \mathrm{Zn}$ superoxide dism-utase and ceruloplasmin activities in copper deficient bovine.Biological Trace Element Research. 37 (3): 269-278.

- Enjalbert, F.; Schelcher, F. and Bed ouet . J.(1997): Study of the relationship between silage feeding and neonatal diarrhoea. Bulletin des. G.T.V.No3,31-37.

- Gierus,M.; Schwarz, F.J. and Kirchgessner(2002): Selenium supplem-entation and selenium status of dairy cows fed diets

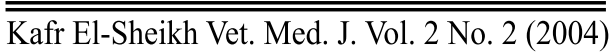


based on grass, grass silage or maize silage. J. Anim. Physiol. Anim. Nutr. 86(3-4): 74-82.

- Gunter,S.A.;Beck,P.A.and Phillips,J.M.(2003): Effects of supplem-entary selenium source on the performance and blood measurements in beef cows and their calves. J. Anim. Sci. 81, 856-864.

- Hidiroglou,N.(1979): Trace elements deficiencies and fertility in rum-inants. J. Dairy Sci., 62: 1195-12o6.

- Jones,D.G.; and Suttle,N.F.(1981): Some effects of copper deficiency on leukocyte function in sheep and cattle. Res. Vet. Sci. 31: 151-156.

- Kelly, W.R. (1990): Veterinary Clinical Diagnosis. $4^{\text {th }}$ ed. Bailler. Tindall, London.

- Kilching and Freiburg,B.(1951): Inorganic phosphorus and alkaline phosphatases in serum. In "Clincal Photometry 3rd ed. Wiss, Verl.Ges. M6H Stutgart.

- Machen, M.; Mabgomery, T.; Holland., P.; Braselbon, Eu.; Nstan.R.; Brewer,G. and Yuzbasyan , V. (1996): Bovine hereditary zinc defic-iency. Lethal trait. A 46. J.Vet. Biagn Lnvest Apr. 8,2: 219 - 227.

- McDonald,T.A.,Smith, W.H.,Pickett, R.A.and Beeson,W.M. (1966): Influence of aged corn and supplemented vitamin A on growing finis-hing swine. J. Anim. Sci. 25, 1024

- Mullis, L.A.;Spears,J.W.and McCraw,R.L.(2003): Estimated copper requirements of Angus and Simmental Heifers J.Anim. Sci., 81,865-873.

- Nasr, M.Y.(1993): Nutritional disturbance among buffalo veals.Ph.D. Thesis, Fac. Vet. Med. Zagazig Univ.

- Nasser, J.H.; Nassif, M.N. Nasr, M.Y. and Naima, A. Afifi (2000): Some biochemical alterations associating achromotrichia and alopecia in buffalo calves with a trial of treatment. J. Egypt. Med. Ass. 60(3): 115-122.

Kafr El-Sheikh Vet. Med. J. Vol. 2 No. 2 (2004) 
- Nobert, W.T.(1986): Method of determination of vitamin A and $\beta$ - carotene. Text Book of Clinical Chemistry $1^{\text {st }}$ ed., W.Saunders Company Philadelphia, London, Mexico,Toronto:336-360.

- NRC.(1996): Nutrient Requirement of Dairy Cattle National Academy of Sciences Washington D.C.

- NRC.(2002): Nutrient Requirements of Dairy Cattle National Academy of Sciences washington D.C.

- Pechin, 6.H; Diart, J.L; Cesh, S.B.; Corbellini, C.N. and Moralego, R. H. (1999): Evaluation of two methods of copper adminsteration (oral and parentral) in beef cattle. Veterinaria Argentine.16(159):651-657.

- Perry, T.W.; Coldwell, D.M. and Paterson, R.C. (1976): Selenium content of feeds and effect of dietary selenium on hair and blood serum. J. Dairy Sci. 59(4): 760-763.

- Pond, D.C.; Church,P. and Pond, K.Rf. (1995): Basic Animal Nutr-ition and Feeding. Printed in USA, New York P. 185.

- Radostits,O.M.;Blood, D.C. and Gay, C.C. (2000): Veterinary Med-icine, $9^{\text {th }}$ ed. Bailierce, Tindal, London, Philadelphia.

- Randhawa, S.S; Arora, C.I.; Randhawa, S.S. and Josh,B.P(1994): Therapeutic evaluation and hair mineral profile of Leukodermic Buffa-loes.In proceeding $18^{\text {th }}$ World Butrics Congress: 26 Congress of Italian Associ. Of Buiatrics, Bolongna, Italy.

- Smith, B.P. (2002): Large Animal Internal Medicine $3^{\text {rd }}$ ed., London, Philadelphia Sydney Toronto.

- SPSS, (1995): Software packet for statisical analysis (Under Window USA).

- Stable,J.R.;Spears, J.W.; Brown,T.T.and Brake,J. (1989): Selenium effect on glutathione peroxidase and immune response 
of stressed calves challenged with Pasteurella haemolytica. J.Anim. Sci. 67(2): 557-564.

- Tilden, W.P. and Michael, J.C. (1995): Beef cattle feeding and nutri-tion.Academic Pressf,San Diego, New York, Boston, London, Sydney, Tokyo, Toronto.

- Weichsclbaum , J.E. (1946): An accurate and rapid method for deter-mination of proteins in small amount of blood serum and plasma. Am-J-Clin- Path - 10:40-48.

- Xin,Z.; Waterman, D.F.; Hemken, R.W. and Harman, R.J (1991): Effect of copper status on neutrophil function, supperoxide dismutase and copper distribution steers. J.Dairy Sci. 74:3078 -3085.

- Yavuz, M.; Mert, N. and Erdinc, H. (1991): Biochemical studies on hypovitaminosis A in beef cattle. Veterinary Farwltesi Dergisi Uludaga Universitesi. 8,9 : 1-3.

$$
\begin{aligned}
& \text { أداء وبعض مكونات الدم لعجول الجاموس النامية و التي تتغذى على } \\
& \text { على علائق تحتوي على سيلاج الذرة } \\
& \text { مدحت ناصف محمد }
\end{aligned}
$$

قسم طب الحيوان - كلية الطب البيطري بكفر الثيخ - جامعة طنطا

أجريت هذه الدراسة على عدد عشرون عجل جاموسي في عمر النمو (6-9 شهور) والتي تزن 120 كجم في مزرعة للإنتاج الحيواني ببلقاس - محافظة الدقهلية ـ وقد ثم تقسيم هذه الحيوانات إلى مجموعنين كل مجموعة بها عشرة عجول حيث تغذت المجموعة الأولى (المجموعة المصابة) على سيلاج الذرة فقط لمدة ثلاثة شهور ، أما المجموعة الثانية (مجموعة المقارنة السليمة) تغذت على علف مركز وقش أرز بالإضافة إلى دريس برسيم. وقد لوحظ ظهور أعراض إكلينيكية على المجموعة الأولى في صورة ضعف عام وهزال وبطء في معدل النمو وفقدان لوزن الجسم وتساقط للثعر في بعض أجزاء 
الجسم وكذا نقص في صبغة الثعر بالإضافة لإسهال وإفرازات دمعية من العينين وكحة في بعض ألعض العجول • وقد أتضح من تحليل العليقة أن سيلاج الذرة غير متزن غذائيا بالنسبة لعجول الجاموس النامية حيث به نقص كبير في كل من البروتين الخام والكالسيوم وبعض العناصر النادرة وخاصة النحاس ،المنجنيز ،السيلنيوم ،الزنك وقد أظهر فحص صورة الدم وجود أنيميا ( hypochromic (microcytic الناجمة عن نقص عنصر النحاس وهذا ما أكده التحليل البيوكيميائى لسيرم دم المجموعة الأولى حيث أنضح أن هناك نقص معنوي في العناصر المعنية السابق ذكرها وكذلك نقص في كل من فيتامين (أ ) والبروتين الكلى في الدم هذا بالمقارنة بالمجموعة الثانية (لعجول السليمة). ولقد استجابت حيوانات المجموعة الأولى لإضافة الأملاح المعدنية مع العليقة المركزة بالإضافة إلى حقن عنصر النحاس وفيتامين (أ). حيث اختقت الأعراض الإكلينيكية مع حدوث تحسن في الثكل الظاهري للعجول مع زيادة في الوزن وتحسن ملموس في قياسات الدم نحو المستويات الطبيعية. 